
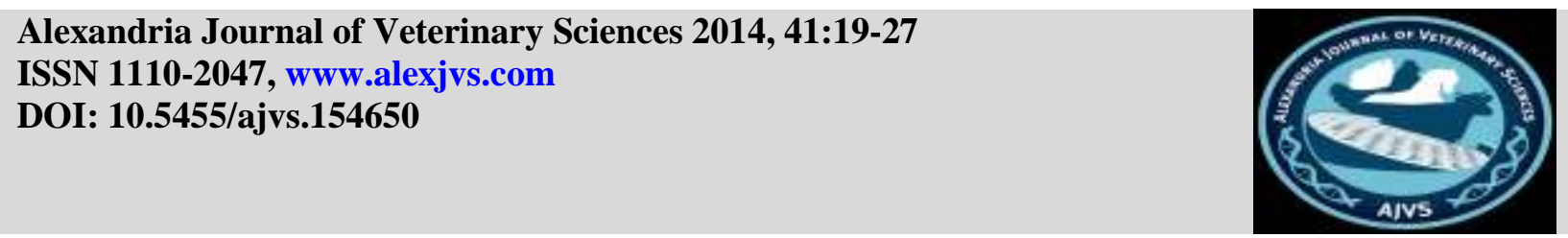

\title{
Influence of Combined Administration of Turmeric and Black Seed on Selected Biochemical Parameters of Diabetic Rats
}

Corresponding Author: Sabry M. El-Bahr: e-mail: sabryelbahr@hotmail.com;

\section{INTRODUCTION}

Diabetes is one of the most common chronic diseases affecting more than 100 million people worldwide. The two major types of diabetes mellitus are characterized by hyperglycemia, abnormal metabolism of lipid and protein with specific long term complications affecting the retina, kidney and nervous system (Mathur et al., 2011). Hyperglycemia is an important factor in the development and progression of the complications of diabetes mellitus (Luzi, 1998). The literature on medicinal plants with hypoglycemic activity is vast. Many of these plants were used for many centuries without any side effects. However chronic consumption of large amounts of traditional remedies must be taken with caution as toxicity studies have not been conducted for most of these plants (Shnkar et al., 1980).

Turmeric (Curcuma longa) is a perennial herb that grows to a height of three to five feet and is cultivated extensively in Asia (India and China) and other countries with a tropical climate. Curcumin, is the active ingredient of turmeric and is a potent antioxidant and anti-inflammatory agent with hepatoprotective, anticarcinogenic and 
antimicrobial properties (Duvoix et al.,2005; Aggarwal et al., 2005) . Curcumin also has a beneficial effect on blood glucose in diabetics and increases gastric mucosal secretion in rabbits (Arun and Nalini 2002). The Turmeric rhizomes have been reported to possess antidiabetic properties as its alcohol extract possesses active constituents showing blood glucose lowering activity in alloxan induced diabetic rats (Shnkar et al., 1980). Black cumin seed (Nigella sativa) is herbaceous plant which is a member of the Ranunculocea family. Black seed induced significant reduction in blood glucose and cholesterol levels in humans (Bamosa et al., 1997). Black cumin seed has been found to rank high among the antidiabetic plants most recommended by traditional practitioners (Haddad et al., 2003). Many studies have also examined the antidiabetic effect of Black cumin seed (Nigella sativa) in normal and in diabetic animal. Beside the effect of crude aqueous extract of Black cumin seed on glucose homeostasis (Labhal et al., 1997) its petroleum ether extract significantly lowered fasting plasma levels of insulin and triglycerides and normalized high density lipoprotein cholesterol (HDL-c) (Le et al., 2004). Because of publications regarding the antidiabetic effect of Turmeric and black cumin seed mixture are scarce, the present study was conducted to study the synergistic efficacy of both plants as a mixture on blood glucose level, water and food intake, body weight and some biochemical parameters in STZ induced diabetic rats.

\section{MATERIALS AND METHODS \\ 2.1. Preparation of plant suspension}

The whole Black cumin seeds were crushed in a blender and $12.5 \mathrm{~g}$ of the seeds was added to $100 \mathrm{ml}$ distilled water at room temperature to prepare a crude suspension a few minutes before experiment (Al-Ghamdi, 2001). Turmeric powder was mixed with distilled water (Meddah et al., 2009; Mills and Bone 2000). The Black cumin seed was used in a dose of $1 \mathrm{~g} / \mathrm{kg}$ body weight and mixed with Turmeric powder in a dose of $0.5 \mathrm{~g} / \mathrm{kg}$ body weight. The dose used in the current experiment was the half of the doses used in previous works for Black cumin seed (Labhal et al., 1997; Le et al., 2004; Meddah et al., 2009) and Turmeric (Arun and Nalini 2002) because plants were used in a combination.

\subsection{Experimental animals}

A total of twenty one male albino rats (3 months old) weighing between 185-200 g were housed in clean and disinfected cages. Commercial basal diet and water were provided ad libitum. Rats were subjected to natural photoperiod of $12 \mathrm{hr}$ light:dark cycle throughout the experimental period (6 weeks). All rats received basal diet for two weeks before the start of the experiment for adaptation and to ensure normal growth and behavior. Rats were maintained in their respective groups for six weeks, monitored closely every day and weighed every week. The food of rats was weighed every day before and after feeding the animals to determine the daily food intake.

\subsection{Induction of experimental diabetes}

Diabetes was induced by administering intraperitonial injection of a freshly prepared solution of STZ (60 mg/kg b. w.) in $0.1 \mathrm{M}$ cold citrate buffer $(\mathrm{pH} 4.5)$ to the overnight fasted rats (Sekar et al., 1990). After 72 hours, fasting blood glucose levels were monitored. Animals having blood glucose values above $250 \mathrm{mg} / \mathrm{dl}$ on the third day after STZ injection were considered as diabetic rats (Tank et al., 1989). Then the treatment was started on the third day after STZ injection and it was considered as first day of treatment.

\subsection{Experimental design and sampling analysis}

The rats were divided into three groups (7 rats each).

Group 1: non diabetic control rats (negative control).

Group 2: Diabetic control rats (positive control).

Group 3: Diabetic rats treated with black cumin seed $(1 \mathrm{~g} / \mathrm{kg}$ b.wt. per day) mixed with turmeric $(0.5 \mathrm{~g} / \mathrm{kg}$ b.w. per day) in aqueous solution orally for six weeks.

Daily measurements of body weight, and water and food intake were recorded. For blood glucose level estimation, blood samples 
were collected from the fasted rats of three groups prior to the treatment with plants and three times per weeks after oral administration of the treatments up to 6 weeks. The blood samples were collected by snipping tail with sharp razor and blood glucose level was then measured immediately by glucose strips (haemo-glucotest). In addition, blood samples were collected without anticoagulant for serum separation. Serum was separated by centrifugation for $10 \mathrm{~min}$ at $3000 \mathrm{rpm}$ and was immediately frozen at $-20^{\circ} \mathrm{C}$ until the time of analysis. The sera were used for spectrophotometric determination of the activities of Aspartate Transaminase (AST) and Alanine Transaminase (ALT) (Reitman and Frankel, 1957). In addition, total protein (Doumas et al., 1981), albumin (Reinhold, 1953), globulin, uric acid (Tabacco et al., 1979), creatinine (Henry, 1984), triacylglycerol (TAG) (Sidney and Bernard 1973) and total cholesterol (Zak et al., 1954) were also determined. Very low density lipoprotein cholesterol (VLDL-c) was calculated by division of TAG by 5 (Bauer, 1982). Calcium, phosphorus and magnesium were determined by using commercial kits on chemistry analyzer according to the manufacturer instructions.

\subsection{Statistical analysis}

All the grouped data were statistically evaluated and the significance of changes

Table 1 Effect of oral administration of Turmeric and Black cumin seed mixture for six weeks on body weight gain $(\mathrm{g})$ in streptozotocine diabetic rats.

\begin{tabular}{llcc}
\hline Groups & \multicolumn{2}{c}{ Body weight $(\mathrm{g})$} & Gain in body weight $(\mathrm{g})$ \\
\cline { 2 - 3 } & Initial & Sixth weeks & \\
\hline I & $195 \pm 5.1$ & $255 \pm 6.2^{\mathrm{a}}$ & 60 \\
II & $194 \pm 7.2$ & $164 \pm 7.1^{\mathrm{c}}$ & -30 \\
III & $194 \pm 6.1$ & $214 \pm 5.2^{\mathrm{b}}$ & 20 \\
\hline
\end{tabular}

I (non diabetic), II (diabetic), III (diabetic treated with plant mixture), Values are mean \pm SD of 7 rats, Means within the same column with different letters are significantly differed $(\mathrm{P} \leq 0.05)$.

Table 2 Effect of oral administration of Turmeric and Black cumin seed mixture for six weeks on water intake ( $\mathrm{ml} /$ day) in streptozotocine diabetic rats.

\begin{tabular}{lcccc}
\hline Groups & \multicolumn{4}{c}{ Water intake (ml/day) } \\
\cline { 2 - 5 } & $1^{\text {st }}$ week & $2^{\text {nd }}$ week & $4^{\text {th }}$ week & $6^{\text {th }}$ week \\
\hline I & $50 \pm 3.3^{\mathrm{c}}$ & $51 \pm 5.1^{\mathrm{c}}$ & $55 \pm 4.1^{\mathrm{c}}$ & $60 \pm 4.6^{\mathrm{c}}$ \\
II & $100 \pm 5.2^{\mathrm{a}}$ & $95 \pm 5.2^{\mathrm{a}}$ & $90 \pm 5.1^{\mathrm{a}}$ & $87 \pm 4.7^{\mathrm{a}}$ \\
III & $70 \pm 5.5^{\mathrm{b}}$ & $75 \pm 2.1^{\mathrm{b}}$ & $75 \pm 5.1^{\mathrm{b}}$ & $75 \pm 2.9^{\mathrm{b}}$ \\
\hline
\end{tabular}

I (non diabetic), II (diabetic), III (diabetic treated with plant mixture), Values are mean \pm SD of 7 rats Means within the same column with different letters are significantly differed $(\mathrm{P} \leq 0.05)$. caused by various treatments was determined using Students t-test (Chou, 1975). The appropriate, one way ANOVA was also done.

\section{RESULTS}

The present findings (Table 1) showed that the control rats (group I) gained weight over the six weeks of the experimental period, with an average body weight increasing by 60 grams. Moreover, the weeks $(P<0.05)$. When these diabetic rats treated with a mixture of Black seed and diabetic control rats.

that, water intake in untreated diabetic groups (Group II) were significantly $(P<0.05)$ increased by $100 \%$ than non-diabetic normal (group I). When these diabetic rats treated $(P<0.05)$ throughout the entire intervals of the experiment. from seven rats in average of 30 grams of their weight after six water intake in diabetic rats was decreased 
Table 3. Effect of oral administration of Turmeric and Black cumin seed mixture for six weeks on feed intake ( $\mathrm{g} /$ day) in streptozotocine diabetic rats.

\begin{tabular}{lllll}
\hline Groups & \multicolumn{4}{c}{ Food intake $(\mathrm{g} /$ day) } \\
\cline { 2 - 5 } & $1^{\text {st }}$ week & $2^{\text {nd }}$ week & $4^{\text {th }}$ week & $6^{\text {th }}$ week \\
\hline I & $15 \pm 2.1^{\mathrm{c}}$ & $17 \pm 1.2^{\mathrm{c}}$ & $20 \pm 1.1^{\mathrm{c}}$ & $22 \pm 2.1^{\mathrm{c}}$ \\
II & $38 \pm 1.9^{\mathrm{a}}$ & $40 \pm 1.5^{\mathrm{a}}$ & $39 \pm 1.4^{\mathrm{a}}$ & $41 \pm 1.7^{\mathrm{a}}$ \\
III & $22 \pm 1.7^{\mathrm{b}}$ & $26 \pm 1.1^{\mathrm{b}}$ & $25 \pm 2.1^{\mathrm{b}}$ & $30 \pm 1.4^{\mathrm{b}}$ \\
\hline
\end{tabular}

I (non diabetic), II (diabetic), III (diabetic treated with plant mixture), Values are mean \pm SD of 7 rats Means within the same column with different letters are significantly differed $(\mathrm{P} \leq 0.05)$.

Table 4 Effect of oral administration of Turmeric and Black cumin seed mixture for six weeks on blood glucose concentration $(\mathrm{mg} / \mathrm{dl})$ in streptozotocine diabetic rats

\begin{tabular}{lclcc}
\hline Groups & \multicolumn{4}{c}{ Blood glucose concentration $(\mathrm{mg} / \mathrm{dl})$} \\
\cline { 2 - 5 } & $1^{\text {st }}$ week & $2^{\text {nd }}$ week & $4^{\text {th }}$ week & $6^{\text {th }}$ week \\
\hline I & $99 \pm 2.1^{\mathrm{c}}$ & $100 \pm 1.2^{\mathrm{c}}$ & $98 \pm 1.1^{\mathrm{c}}$ & $96 \pm 2.1^{\mathrm{c}}$ \\
II & $350 \pm 1.9^{\mathrm{a}}$ & $355 \pm 1.5^{\mathrm{a}}$ & $360 \pm 1.4^{\mathrm{a}}$ & $355 \pm 1.7^{\mathrm{a}}$ \\
III & $250 \pm 1.7^{\mathrm{b}}$ & $240 \pm 1.1^{\mathrm{b}}$ & $245 \pm 2.1^{\mathrm{b}}$ & $240 \pm 1.4^{\mathrm{b}}$ \\
\hline
\end{tabular}

I (non diabetic), II (diabetic), III (diabetic treated with plant mixture), Values are mean \pm SD of 7 rats Means within the same column with different letters are significantly differed $(\mathrm{P} \leq 0.05)$.

Data summarized in Table 3 revealed that feed intake in untreated diabetic groups (Group II) were significantly $(P<0.05)$ increased by $153 \%$ than non-diabetic normal rats (group I). When these diabetic rats treated with a mixture of Black seed and Turmeric, $39.5 \%$ of the increase in feed intake in diabetic rats was reduced $(P<0.05)$ throughout the entire intervals of the experiment.

The results for the effects of Turmeric and Black cumin seed mixture on blood glucose concentration of diabetic rats are shown in Table 4. At the start of the experiment, there were no significant $(P>0.05)$ differences in the mean values of blood glucose level between all experimental groups. After injection of STZ, the mean values of blood glucose levels in untreated diabetic rats (group II) were remained above $350 \mathrm{mg} / \mathrm{dl}$ during the entire period of the experiment, which were significantly $(P<0.05)$ higher than those of the non-diabetic normal control rats by $253.3 \%$. The percentage of increase in glucose level of diabetic rats $(253.3 \%)$ was reduced by $28.6 \%$ $(250 \mathrm{mg} / \mathrm{dl})$ when they treated with plants combination.
The results presented the effect of Turmeric and Black cumin seed mixture on protein patterns, lipid profile, liver and kidney functions and electrolytes were presented in Table 5. These findings indicated that, STZ induced significant $(P<0.05)$ increase in total cholesterol values by $31.3 \%$ compared with normal non diabetic rats. The plants combination restored the cholesterol to normal level. The present findings indicated also that, STZ induced significant $(P<0.05)$ increase in TAG values by $9 \% \quad(142 \pm$ $3.4 \mathrm{mg} / \mathrm{dl}$ ) compared with normal non diabetic rats $(130 \pm 4.1 \mathrm{mg} / \mathrm{dl})$. Combined administration of plants reduced this increase till reached $41.5 \%(76 \pm 4.1 \mathrm{mg} / \mathrm{dl})$ lower than the normal control level $(130 \pm 4.1 \mathrm{mg} / \mathrm{dl})$. The other examined biochemical values remained unchanged throughout the experimental period.

\section{DISCUSSION}

Growth promoters are commonly added to the animals feed for growth enhancement and efficient feed utilization. They are chemical products, antibiotics, enzymes and/or natural extractives. Since the use of chemical products antibiotics might have some unfavorable side effects, therefore researchers tended to use natural additives 
which meet the requirements of good growth promoting agents (Fluk et al., 1976). Medicinal plants have received increasing attention as spices for human and additive in diets for animals. In the present study, we tried to examine the antidiabetic effect of Black cumin seed and Turmeric mixture in experimentally induced diabetic rats, since the publication concerning this issue are limited. Injection of STZ in rats caused significant increase in blood glucose level. Using 60 $\mathrm{mg} / \mathrm{kg}$ STZ dose induced an autoimmune process that resulted in the destruction of the B-cells of the islets of Langerhans and the same dose of STZ resulted in the toxicity of ß-cells with emergence of clinical diabetes within 2-4 days (Weiss, 1982). Previous articles (Hussain, 2002; Sellamuth et al., 2009) indicated that, STZ diabetic rats are hyperglycemic and have increased oxidative stress. This is also in consistent with the fact that blood glucose level might have increased due to gluconeogenesis in the absence of insulin (Yao et al., 2006). On other hand, the present study revealed that Turmeric and Black cumin seed mixture was effective in reducing blood glucose concentration. The hypoglycemic effect of Turmeric comes in accordance with those obtained in rats (Arun and Nalini 2002; Sharma et al., 2006). Authors reported that curcumin, the active principles of Turmeric had a beneficial effect on blood glucose in diabetics and increases gastric mucosal secretion in rabbits. The inclusion of curcumin at $0.6-0.9 \mathrm{~g} / \mathrm{kg}$ diet improved the adverse effect of aflatoxins in blood glucose values of broiler chicken (Ahmadi, 2010). The present results concerned the hypoglycemic effect of plant mixture agrees with those reported the antidiabetic effect of Turmeric rhizomes in alloxan induced diabetic rats (Shnkar et al., 1980) and with others (Haddad et al., 2003; Labhal et al., 1997; El-Bagir et al., 2010) that demonstrated the hypoglycemic effect of Black cumin seed. The antidiabetic effect of Turmeric perhaps attributed to the antioxidant activity of curcumin against oxidative tissue damage (Joe and Lokesh, 1994) whereas, the antidiabetic effect of Black cumin seed perhaps explained by an insulin-like stimulation of glucose uptake by muscle and adipose tissue (Benhaddou-Andaloussi et al., 2010) or inhibition of intestinal glucose absorption (Meddah et al., 2009).

Table 5 Effect of oral administration of Turmeric and Black cumin seed mixture for six weeks on selected biochemical parameters in streptozotocine diabetic rats

\begin{tabular}{llll}
\hline Parameters & Group I & Group II & Group III \\
\hline Total Protein $(\mathrm{g} / \mathrm{l})$ & $5.5 \pm 0.2$ & $5.4 \pm 0.1$ & $5.6 \pm 0.1$ \\
Albumin $(\mathrm{g} / \mathrm{l})$ & $3.2 \pm 0.2$ & $3.3 \pm 0.1$ & $3.4 \pm 0.2$ \\
Globulin $(\mathrm{g} / \mathrm{l})$ & $2.3 \pm 0.2$ & $2.1 \pm 0.1$ & $2.2 \pm 0.1$ \\
A/G ratio & $1.4 \pm 0.1$ & $1.6 \pm 0.1$ & $1.5 \pm 0.1$ \\
Total cholesterol (mg/dl) & $48 \pm 2.2^{\mathrm{b}}$ & $63 \pm 3.5^{\mathrm{a}}$ & $49 \pm 2.3^{\mathrm{b}}$ \\
TAG (mg/dl) & $130 \pm 4.1^{\mathrm{b}}$ & $142 \pm 3.4^{\mathrm{a}}$ & $76 \pm 4.4^{\mathrm{c}}$ \\
ALT (U/l) & $19 \pm 1.2$ & $18 \pm 1.4$ & $20 \pm 2.4$ \\
AST (U/l) & $100 \pm 4.5$ & $102 \pm 4.1$ & $100 \pm 4.4$ \\
BUN (mg/dl) & $4.1 \pm 1.6$ & $3.8 \pm 2.1$ & $5.1 \pm 2.0$ \\
Uric acid (mg/dl) & $2.1 \pm 0.3$ & $2.3 \pm 0.2$ & $2.0 \pm 0.1$ \\
Creatinine (mg/dl) & $0.5 \pm 0.1$ & $0.6 \pm 0.2$ & $0.6 \pm 0.1$ \\
Calcium & $10.6 \pm 2$ & $11.5 \pm 0.8$ & $10.5 \pm 1$ \\
Phosphorus & $2.1 \pm 0.2$ & $4.5 \pm 1.9$ & $2.6 \pm 0.8$ \\
Magnesium & $1.5 \pm 0.9$ & $0.8 \pm 0.2$ & $1.0 \pm 0.3$ \\
Chloride & $109.6 \pm 16$ & $104.6 \pm 5.5$ & $107.2 \pm 4.5$ \\
\hline
\end{tabular}

I (non diabetic), II (diabetic), III (diabetic treated with plant mixture), Values are mean \pm SD of 7 rats Means within the same column with different letters are significantly differed $(\mathrm{P} \leq 0.05)$. 
The present study also showed that, injection of rats with STZ lead to reduction of mean value of body weight accompanied by an increase in the mean values of food and water intake. These findings further support the fact that the most classic symptoms for diabetes mellitus are Polyuria, Polydipsia and Polyphagia. Poor or defect of glucose utilization can also lead to weight loss and sense of fatigue despite of normal or even increased of food intake (Irshaid et al., 2010). In addition, body weight loss and fatigue can also result due to loss of fluid. The animals should increase food and water intake to compensate for loss of body weight and fluid as a consequence to such changes (Irshaid et al., 2010). On other hand, the present data also revealed that treatment of diabetic rats with Turmeric and Black cumin seed mixture appears to have positive effects on body weight gain as well as in reduction of both food and water intake. These ameliorative effects might be explained by the partial reduction in blood glucose levels in STZ induced diabetic rats. However, another study (Ahmadi, 2010) reported that, oral administration of Turmeric $(0.3$ or $0.6 \mathrm{~g} / \mathrm{kg}$ diet) had no effect on growth performance of broiler chicken. An increase in body weight gain in rats fed different concentration of Black cumin seed was reported (El-Bagir et al., 2010) whereas in the contrary, oral administration of methanol extracts of Black cumin seed lowered body weight in mice (Vahdati-Mashhadian et al., 2005). Interestingly, the effect of combined mixture of Black cumin seed and Turmeric was investigated only in fish (El-Bahr and Saad 2008). The dietary supplementation of Black cumin seed and Turmeric $(5 \mathrm{~g} / \mathrm{kg}$ diet $)$ improved performance and biochemistry of Mugil Cephalus (El-Bahr and Saad 2008).

The unchanged serum total proteins, albumin and globulin values in STZ diabetic rats treated with plant mixture disagree with the findings observed in Mugil cephalus fish (El-Bahr and Saad 2008) when the same dose of plant mixture was used. The present results concerning biochemistry disagree with previous researches demonstrating the positive effect of Black cumin seed in biochemical parameters of Nile tilapia (Hussain, 2002), Catfish (Ezat, 2005), Pekin ducklings (El-Bahr, 2007) and Mugil Cephalus fish (El-Bahr and Saad 2008) and disagree also with the results concerning the positive effect of Turmeric in biochemical values of mice (Antony et al., 1999), rats (Salama and El-Bahr 2007) and Mugil Cephalus fish (El-Bahr and Saad 2008). However, this difference perhaps attributed to different species, dose and experimental period. The increased activity of AST in STZ induced diabetic rats indicated liver dysfunction as reported before in rats (Saeed et al., 2008). Liver damage was observed after oral administration of aqueous extract of Nigella sativa $(10 \mathrm{ml} / \mathrm{kg}$ of body weight for 14 consecutive days) in rats (Tennekoon et al., 1991) or in mice after oral administration of an aqueous extract of the Black cumin seeds in 4 different doses, 6, 9, 14 and $21 \mathrm{~g} / \mathrm{kg}$ (Vahdati-Mashhadian et al., 2005). In addition the same liver damage was observed in ducklings kept on powdered Black cumin seed $(20 \mathrm{gm} / \mathrm{kg}$ diet) (El-Bahr and Saad 2008). The liver damage observed in the previous studies (Tennekoon et al., 1991; Vahdati-Mashhadian et al., 2005; El-Bahr, 2007) disappeared in the present study and that might be attributed to difference in plant source, dosage, route of administration, species, age and administered ingredients. The present study reported non-significant changes in liver and kidney function in all groups. These results come in accordance with the previous findings (Abubakar et al., 2009) demonstrated that diabetes induction caused insignificant changes in serum levels of ALT, AST, urea and creatinine. In the contrary, the present findings also disagree with others (Saeed et al., 2008) demonstrated an increase in blood urea nitrogen and uric acid in STZ induced diabetic rats indicated kidney dysfunction.

Diabetes induced many changes in lipid profile as hyperlipidemia and hypercholesterolemia observed in STZ diabetic rats come in accordance with the previous studies in rats (Hussain, 2002; Soni 
and Kuttan 1992). The antihyperlipidemic and antihypercholesterolemic effect of Turmeric was reported before in rats (Kim and Kim 2010). Administration of $500 \mathrm{mg}$ curcumin to human volunteers for one week did not produce significant change in serum cholesterol level (Soni and Kuttan 1992). Additionally, consumption of Curcumin over 1 month or 6 months was reported not to affect blood concentrations of $\mathrm{TG}$, or $\mathrm{TC}$, LDL, and HDL-c (Baum et al., 2007). The hypocholesterolemic effect of Turmeric reported to be due to up-regulation of cholesterol $7 \alpha$-hydroxylase in rats (Kim and Kim 2010). Hypolipidemic and hypocholesterolemic effect of Black cumin seed come in accordance with previous research in rats (Baum et al., 2007; Kocyigit et al., 2009; Nader et al., 2010). In the contrary, hypercholesterolemic and hyperlipidemic effects followed oral administration of Black cumin seed $(2 \%)$ in Pekin ducklings were recorded (El-Bahr and Saad, 2008). The hypolipidemic effect of Black cumin seed may be attributed to the synergistic effect of its different constituents, soluble fiber, sterols, flavenoids and high content of polyunsaturated fatty acids. Hypolipidemic effect of soluble fibers contents of Black cumin seed might be related to decreased cholesterol absorption and increased bile acid synthesis and degradation (Ali and Blunden 2003). The hypocholesterolemic effect of black cumin seed may relate to up-regulation of low density lipoprotein receptors and inhibition of 3-hydroxy 3-methylglutaryl coenzyme A reductase (Al-Naqeep et al., 2009). The present study can concluded that, dietary supplementation of Turmeric and Black seed mixture to diabetic rats was effective in reducing blood glucose, water and food intake, TAG and Cholesterol accompanied by an increase in body weight gain in STZ diabetic rats.

\section{REFERENCES}

Abubakar, G., Danladi, A.A., Sunday, E.A., Sani, I. 2009. Antidiabetic Effect of Nauclea latifolia Leaf Ethanolic Extract in
Streptozotocin-induced Diabetic Rats. Phcog Res. 1: 392-395.

Aggarwal, B.B., Kumar, A., Aggarwal, M.S., Shishodia, S. 2005. Curcumin derived from turmeric (Curcuma longa): a spice for all seasons. In: Preuss, H. G. editor, Phytopharmaceuticals in Cancer Chemoprevention. CRC, USA. 349-387.

Ahmadi, F. 2010. Effect of turmeric (Curcumin Longa) powder on performance, oxidative stress state and some of blood parameters in broiler fed on diets containing aflatoxin B1. Global Vet. 5: 312-317.

Al-Ghamdi, M.S. 2001. The antiinflammatory, analgesic and antipyretic activity of Nigella sativa. J Ethnopharmacol. 76: 45-48.

Ali, B.H., Blunden, G. 2003. Pharmacological and toxicological properties of Nigella sativa. Phytother Res. 17: 299-305.

Al-Naqeep, G., Ismail, M., Allaudin, Z., 2009. Regulation of low-density lipoprotein receptor and 3-hydroxy-3-methylglutaryl coenzyme A reductase gene expression by thymoquinone-rich fraction and thymoquinone in HepG2 cells. J. Nutrigenet. Nutrigenomics 2: 163-172.

Antony, S., Kuttan, R., Kuttan, G. 1999. Immunomodulatory Activity of Curcumin. Immunol. Invest. 28: 291-303.

Arun, N., Nalini, N. 2002. Efficacy of turmeric on blood glucose and polyol pathway in diabetic albino rats. Plant Foods for Human Nutrition. 57: 41-52.

Bamosa, A.O., Ali, B.A., Sowayan, S.A. 1997. Effect of oral ingestion of Nigella sativa seeds on some blood parameters. Saudi Pharm. J. 5: 126-129.

Bauer, J.D. 1982. Clinical laboratory methods 9th edition. The C.V. Company II 1830, Westline industrial, Missouri.

Baum, L., Cheung, S.K., Mok, V.C., Lam, L.C., Leung, V.P., Hui, E, Ng, C.C., Chow, M., Ho, P.V., Lam, S., Woo, J., Chiu, H.F., Goggins, W., Zee, B., Wong, A., Mok, H., Cheng, W.K., Fong, C., Lee, J.S., Chan, M.H., Szeto, S.S., Lui, V.W., Tsoh, J., Kwok, T.C., Chan, I.H., Lam, C.W. 2007. Curcumin effects on blood lipid profile in a 6-month human study. Pharmacol Res. 56: 509-514. 
Benhaddou-Andaloussi, A., Martineau, L.C., Vallerand, D., Haddad, Y., Afshar, A., Settaf, A., Haddad, P.S. 2010. Multiple molecular targets underlie the antidiabetic effect of Nigella sativa seed extract in skeletal muscle, adipocyte and liver cells. Diabetes Obes. Metab. 12: 148-157.

Chou, YH. 1975. Experimental design and the analysis of variance, Statistical Analysis-I. New York, Holt, Reinhart and Winston Publication. 340-352.

Doumas, B.T., Bayson, D.D., Carter, R.J., Peters, T., Schaffer, R. 1981. Estimation of total serum protein. Clin. Chem. 27: 1642 1643.

Duvoix, A., Blasius, R., Delhalle, S., Schnekenburger, M., Morceau, E., Henry, E., Dicato, M., Diederich, M. 2005. Chemopreventive and therapeutic effects of curcumin. Cancer Lett. 223: 181-90.

El-Bagir, N.M., Farah, I.T.O, Alhaidary, A., Mohamed, H.E., Beynen, A.C. 2010. Clinical laboratory serum values in rabbits fed diets containing black cumin seed. J. Anim. Vet. Adv. 19:2532-2536.

El-Bahr, S.M., Saad, T.T. 2008. Effect of Black cumin seeds (Nigella sativa) and/or Turmeric (Curcumin) on hematological, biochemical and immunological parameters of Mugil cephalus fish vaccinated with Aeromonus hydrophila bacterin. The Thirteen scientific congress, Faculty of Veterinary Medicine, Assuit University, 2528, November. 365-388.

El-Bahr, S.M. 2007. Effect of black cumin seeds (Nigella sativa) on the profile of serum lipids, lipoproteins and fatty acids in pekin ducklings. Int. J. Appl. Chem. (IJAC) 3: 221-230.

El-Sayed, E.M., Abo-Salem, O.M., Aly, H.A., Mansour, A.M. 2009. Potential antidiabetic and hypolipidemic effects of propolis extract in streptozotocin-induced diabetic rats. Pak. J. Pharm. Sci. 22: 168-174.

Ezat, A.M. 2005. Effect of black seed (Nigella sativa) on the immune status of catfish (Clarias gariepinus). Ph.D. (Thesis). Faculty of Veterinary Medicine, Assuit University, Egypt.
Fluck, H., Schib, R.J., Rowson, J.M. 1976. Medicinal Plants and Their Uses. W. Foulsham and Co. Ltd, England. 168.

Haddad, P.S., Depot, M., Settaf, A., Chabli, A., Cherrah, Y. 2003. Comparative survey on the medicinal plants most recommended by traditional practitioners in Morocco and Canada. J. Herbs Spices Med. Plants. 10:2545.

Henry, J.B. 1984. Clinical Diagnosis and management, $17^{\text {th }}$ edition, Saunder Publisher.

Hussain. H.E.M.A. 2002. Hypoglycemic, hypolipidemic and antioxidant properties of combination of curcumin from curcoma longa, linn. and partiallt purified product from Abroma augusta, linn. in streptozotocin induced diabetes. Indian. J. Clin. Biochem. 17: 33-43.

Irshaid, F., Mansi, K., Aburjai, T. 2010. Antidiabetic effect of essential oil from Artemisia sieberi growing in jordan in normal and alloxan induced diabetic rats. Pak. J. Biol. Sci. 13: 423-430.

Joe, B., Lokesh, B.R. 1994. Role of capsaicin, curcumin and dietary n-3 fatty acids in lowering the generation of reactive oxygen species in rat peritoneal macrophages. Biochemica Biophysica Acta. 1224: 255263.

Kim, M., Kim, Y. 2010. Hypocholesterolemic effects of curcumin via up-regulation of cholesterol 7a-hydroxylase in rats fed a high fat diet. Nutr. Res. Pract. 4:191-195.

Kocyigit, Y., Atamer, Y, Uysal, E. 2009. The effect of dietary supplementation of Nigella sativa L. on serum lipid profile in rats. Saudi. Med. J. 30: 893-896.

Labhal, A., Settaf, A., Bennani, N., Cherrah, Y., Slaoui, A., Hassar, M. 1997. Action anti-obésité et hypocholestérolémiante de Nigella sativa chez le rat des sables. Caducée. 27: 26-28.

Le, P.M., Benhaddou-Andaloussi, A., Elimadi, A., Settaf, A., Cherrah, Y., Haddad, P. 2004. The petroleum ether extract of Nigella sativa exerts lipidlowering and insulin-sensitizing actions in the rat. J. Ethnopharmacol. 94: 251-259. 
Luzi, L. 1998. Pancreas transplantation and diabetic complications. The new England J. Med. 339: 115-117.

Mathur, M.L., Gaur, J., Sharma, R., Haldiya, K.R. 2011. Antidiabetic Properties of a spice Plant Nigella Sativa. J. Endocrinol. Metab. 1: 1-8.

Meddah, B., Ducroc, R., Faouzi, M., Eto, B., Mahraoui, L., Benhaddou-Andaloussi, A., Martineau, L.C., Cherrah, Y., Haddad P.S. 2009. Nigella sativa inhibits intestinal glucose absorption and improves glucose tolerance in rats. J. Ethnopharmacol. 121: 419-424.

Mills, S, Bone, K. 2000. Principles and Practice of Phytotherapy. Toronto (ON): Churchill Livingstone.

Nader, M.A., El-Agamy, D.S., Suddek, G.M. 2010. Protective effects of propolis and thymoquinone on development of atherosclerosis in cholesterol-fed rabbits. Arch Pharm Res., 33: 637-643.

Reinhold, R.P. 1953. Determination of serum albumin. Clin Chem. 21: 1370-1372.

Reitman S, Frankel, S.A. 1957. Colorimetric method for the determination of serum glutamic oxaloacetic and glutamic pyruvic transaminases. Am. J. Clin. Pathol. 28:5663.

Saeed, M.K., Deng, Y., Dai, R. 2008. Attenuation of Biochemical Parameters in Streptozotocin-induced Diabetic Rats by Oral Administration of Extracts and Fractions of Cephalotaxus sinensis J. Clin. Biochem. Nutr. 42:21-28.

Salama, A.F., El-Bahr, S.M. 2007. Effect of curcumin on cadmium-induced oxidative testicular damage in rats. J. Med. Res.h Inst. (JMRI). 28: 130-136.

Sekar, N., Kanthasamy, S., William, S., Subramanian, S., Govindasamy, S. 1990. Insulinic actions of vanadate in diabetic rats. Pharmacol. Res. 22: 207-217.

Sellamuthu, P.S., Muniappan, B.P., Perumal, S.M., Kandasamy, M. 2009. Antihyperglycemic Effect of Mangiferin in Streptozotocin Induced Diabetic Rats. J. Health. Sci. 55: 206-214.

Sharma, S., Kulkarni, S.K., Chopra, K. 2006. Curcumin, the active principle of turmeric
(Curcuma longa), ameliorates diabetic nephropathy in rats. Clin. Exp. Pharmacol. Physiol. 33: 940-945.

Shnkar, T.N.B, Shanta, N.V., Ramesh, H.P., Murthy, I.A.S, Murthy, V.S. 1980. Toxicity Studies on Turmeric (Cuecuma longa): Acute Toxicity studies in rats, Guineapigs and Monkeys. Indian J. Exp. Biol. 18: 7375.

Sidney, P.G., Bernard, R. 1973. Improved manual spectrophotometric procedure for determination of serum triglycerides. Clin. Chem. 19: 1077-1078.

Soni, K.B., Kuttan, R. 1979. Effect of oral curcumin administration on serum peroxides and cholesterol levels in human volunteers. Indian J. Physiol. Pharmacol. 1992: 36:273-275.

Tabacco, A., Meiathini, F., Moda, E., Tarli, P. 1979. Simplified enzymic/colorimetric serum urea nitrogen determination. Clin. Chem. 25: 336-337.

Tank, R., Sharma, N., Sharma, I., Dixit, V.P. 1989. Anti-diabetic activity of Curcuma longa in alloxan Induced diabetic rats. Ind. drugs. 27: 587-589.

Tennekoon, K.H., Jeevathayaparan, S., Kurukulasooriya, A.P., Karunanayake, E.H. 1991. Possible hepatotoxicity of Nigella sativa seeds and Dregea volubilis leaves. J. Ethnopharmacol. 31: 283-289.

Vahdati-Mashhadian, N., Rakhshandeh, H., Omidi, A. 2005. An investigation on LD50 and subacute hepatic toxicity of Nigella sativa seed extracts in mice. Pharmazie. 60: 544-547.

Weiss, R.B. 1982. Streptozocin: A review of its pharmacology, efficacy and toxicity. Cancer Treat. Report. 66: 427-438.

Yao, X.H., Chen, L., Nyomba, B.L.G. 2006. Adult rats prenatally exposed to ethanol have increased gluconeogenesis and impaired insulin response of hepatic gluconeogenic. Genes J. Applied. Physiol. 100: 642-648.

Zak, B., Dickenman, R.C., White, E.G., Burnett, H., Cherney, P.J. 1954. Rapid estimation of free and total cholesterol. Am. J. Clin. Pathol. 24: 1307-1315. 